Erratum

\title{
Erratum to "Proposal for the International Society for Cell \& Gene Therapy position statement on assays for the quality control and potency assessment of adoptive cellular immunotherapies" (Cytotherapy 2019;
}

\section{1: 367-375)}

\section{Angela Welch ${ }^{\mathrm{a}}$}

${ }^{\mathrm{a}}$ Elsevier, Inc.

\section{Publisher's Note:}

The Publisher wishes to clarify that the paper titled "Proposal for the International Society for Cell \& Gene Therapy position statement on assays for the quality control and potency assessment of adoptive cellular immunotherapies" was authored by Ben Weil, Patrick J. Hanley, and Mark Lowdell as an Editorial for the Special Issue on Immunotherapy published in Volume 21, Issue 3, March 2019. Due to a production error, this Editorial was published out of sequence, appearing as the last paper in the issue, and was not clearly designated as an Editorial.

We apologize to the Authors and to the community for any inconveniences and misinterpretations that may have resulted from the incorrect labelling and placement of this Editorial within the Special Issue. 